Review article

\title{
Assessment of pain in preschoolers (aged 3-7): A scoping review of existing instruments
}

\author{
Petra Kašparová ${ }^{1}{ }^{*}$, Petra Mandysová ${ }^{2}$ \\ ${ }^{1}$ Palacký University, Faculty of Health Sciences, The Centre for Science and Research, Olomouc, Czech Republic \\ 2 Palacký University, Faculty of Health Sciences, Department of Nursing, Olomouc, Czech Republic
}

\begin{abstract}
Aim: The aim of this study is to evaluate the available scientific knowledge on the assessment of pain in preschool children (aged 3-7). The information obtained will provide a basis for further research.

Methods: The data were collected with the help of keywords by PCC and using Boolean operators that were searched for in scientific electronics databases. The data were collected using keywords that were selected based on a research question and targeted at a specific population, concept and context. Four scientific databases were included: PubMed, ProQuest, OVID, EBSCOhost.

Results: A total of 243 articles were identified, plus another 10 records were identified from the reference list of retrieved articles. After analysis, 51 articles were subjected to a critical analysis and 14 studies were selected for final use for the scoping review.

Conclusions: A literature review confirmed that the topic of pain assessment in childhood is becoming increasingly important. All the presented pain assessment tools assess pain in different ways, but always with the same goal: to properly assess a child's pain and then treat it as best as possible. Particularly with young children, it is advisable to include more methods of pain assessment and to assess more aspects of pain to provide them with the right treatment.
\end{abstract}

Keywords: Assessment tool; Children; Paediatric; Pain; Pain management; Pain scale

\section{Introduction}

Pain is a multidimensional complex of unpleasant sensory and emotional experience associated with actual or potential tissue damage. Pain is a personal experience that is fundamentally influenced by biological, psychological and social factors. Pain can have adverse effects on quality of life, personal functioning and social and mental well-being (Chan and von Baeyer, 2016; International Association for the Study of Pain, 2021; McGrath and McAlpine, 1993). Pain and its subjective perception is multifactorial, and therefore the approach to pain assessment must also be multidisciplinary (Brand and Al-Rais, 2019).

A myth exists that children do not remember pain they have experienced in the past. However, research has shown that children transfer their negative experience of pain into adulthood (Plevová et al., 2012). Children often cry for various reasons including pain - and adults do not pay enough attention to this as they assume that children will forget why they were crying. At the same time, patient care must be the same regardless of whether it concerns a child or an adult. All patients are entitled to the same nursing care. Young children are handicapped in this respect, because they generally do not self-report pain or discomfort (Sedlářová, 2008).

As several studies have shown, information about pain can be obtained from patient self-report, physical response and behavioural manifestations. Self-report is rated as the gold standard. The actual assessment of pain is influenced by the level of cognitive development, the ability to verbalize the pain, and the social environment (Brand and Al-Rais, 2019; Emmott et al., 2017). The importance of self-reporting lies in the fact that it provides information on subjective aspects (Chan and von Baeyer, 2016). It is preferable if children self-assess pain. To do so, it is necessary to offer the child a tool that he or she understands (Plevová et al., 2012; von Baeyer et al., 2011). Alternatively, self-assessment tools should be adapted to the specific age and developmental level of the child, and in all cases, they should be practically applicable in a clinical setting, sufficiently reliable, valid and portable (Brand and Al-Rais, 2019).

However, preschool children (aged 3-7) do not use pain self-assessment as often as needed because children assess their pain in a way that adults understand differently and do not evaluate it correctly (Chan and von Baeyer, 2016; von Baeyer et al., 2011). In practice, pain is assessed by parents

\footnotetext{
* Corresponding author: Petra Kašparová, Palacký University, Faculty of Health Sciences, The Centre for Science and Research, Hněvotínská 3, 77515 Olomouc, Czech Republic; e-mail: petra.kasparova@upol.cz http://doi.org/10.32725/kont.2021.048 
rather than their young child. The result may be inaccurate because the personality and attitude of parents play a significant role. Pain assessed in this way may not be accurate enough for good pain management (Stanley and Pollard, 2013).

The major barrier is that most preschool-aged children do not have the necessary cognitive development to use a standard scale (Chan and von Baeyer, 2016; Emmott et al., 2017). Cognitive skills that are crucial for understanding and correctly evaluating pain include: cognitive flexibility, working memory, a recognition that a symbol represents something else, pain vocabulary, and the understanding of words used by the adult who is giving the instructions (Chan and von Baeyer, 2016). Cognitive flexibility is the ability to compare and sort at least 3 different objects according to size. Children are usually able to recognize what is big and what is small, but they may have problems determining what is medium size until they are 4 or 5 years old. Working memory is the ability to memorize instructions on how to work with the rating scale and work according to the instructions throughout pain assessment. The range of items to remember is proportional to age and gradually increases with mental development. Symbolic processing for the use of pain scales, understanding the symbols and assigning meaning according to the pain scale used requires sufficient mental maturity. One symbol represents the intensity of the pain and the other symbol represents an image of the appropriate pain rating scale (e.g. cube, poker chip, face, toy, animal). The child must be able to maintain both symbols and their relationship. This ability is very demanding and is acquired from 3 to 6 years, and children aged 2 and 3 usually have a problem with this symbolism.

Pain vocabulary develops along with knowledge and memories of pain. Children start using their first word for pain from the age of 18 months (they are syllables, short words). Around the age of 3 they have a children's dictionary of simple words expressing pain. From the age of 5 they can accurately describe the place, cause and intensity of pain (Besenski et al., 2007; Chan and von Baeyer, 2016; von Baeyer et al., 2011). However, the question is to what extent individual cognitive skills have a fundamental influence on self-assessment of pain. We must take into account the individual development of each child with his or her unique socio-economic conditions and previous experience with pain. When it comes to the assessment of pain in a child, there is a large degree of subjective influence of the adult evaluator. The assessment of pain in preschoolers is therefore based on behavioural / observation tools as well as self-report. There is currently no consensus on which approach is best.

\section{Review aims}

The aim was to conduct a scoping review of existing studies that deal with pain assessment in preschool children (aged 3-7) and to use pain assessment tools. Part of the aim was to search for the studies and to synthesize the obtained information, upon which recommendations could be made concerning further research and clinical practice.

\section{Materials and methods}

The scoping review methodology was purposefully chosen to address the above-mentioned objectives. The aim of a scoping review is to answer a specific question (or series of questions) according to very precise classification criteria that are based on the so-called PCC (Population, Concept, Context) question (Table 1) (Peters et al., 2020). The basic review question that led the search strategy process was: "What tools for assessing pain in children are available?" For each part of the PCC question, relevant key words were determined (Table 1). Databases searched included PubMed, ProQuest, OVID, and EBSCOhost. The search period included articles listed in the database since the inception until now (09/2020).

$\begin{aligned} & \text { Table 1. Description of the PCC question and corresponding } \\
& \text { key words }\end{aligned}$
\begin{tabular}{ll} 
PCC question & Keywords \\
\hline $\begin{array}{l}\text { P = population / } \\
\text { participants of } \\
\text { interest }\end{array}$ & child, kid, pediatric, paediatric, boy, girl, preschool \\
C = concept & $\begin{array}{l}\text { assessment tool, pain scale, assessment method, } \\
\text { pain measurement, questionnaire, assessment } \\
\text { instrument, rate, pain, ache, hurt, sore }\end{array}$ \\
C = context & $\begin{array}{l}\text { hospital, community, ambulance, clinic, nursing } \\
\text { care }\end{array}$ \\
\hline
\end{tabular}

\section{Search strategy}

The selected keywords were combined using the Boolean operators AND and OR. An example of PubMed search procedure is: search (child[Title/Abstract]) OR (preschool[Title/ Abstract]) OR (pediatric[Title/Abstract]) OR (paediatric[Title/ Abstract]) OR (boy[Title/Abstract]) OR (girl[Title/Abstract]) AND (Pain Measurement[Title/Abstract]) OR (Pain Scale[Title/Abstract]) OR (Pain Assessment[Title/Abstract]) OR (Pain Questionnaire[Title/Abstract]) AND (pain[Title/Abstract]) OR (ache[Title/Abstract]) OR (sore[Title/Abstract]). The following filters in the PubMed database were used to specify and reduce publications: Abstract, Free full text, Full text, Clinical Study, Clinical Trial, Evaluation Study, Observational Study, Randomized Controlled Trial, Validation Study, Humans, Czech, English.

\section{Identifying relevant studies}

All individual documents had to meet the criteria for a scientific publication and had to focus on the assessment of pain in children. Publications obtained from an extensive search were screened for compliance with the individual criteria (Table 2). Only original research (quantitative, qualitative, combined method, validation and methodological) studies published in a peer-reviewed journal without a time limit were selected for the article. The chosen language of publications was English and $C z e c h$. The participant criterion was children under 7 years of age, or there was at least one subgroup of preschool children. Participants had to experience pain; however, the pain did not have to be specified. The studies had to include a description of the pain assessment tool in order to be included. There were no restrictions concerning geographical areas or environments. Free articles with available full texts were one of the conditions for inclusion in the scoping review.

\section{Study selection}

Based on the search using the terms in the mentioned databases, a total of 243 articles were identified, plus another 10 records were identified from the reference lists of the retrieved articles. All studies were published primarily in English (Fig. 1). After removing duplicate records, 212 articles remained. In the next step, the title, abstract and keywords of the articles were screened to see if they matched the inclusion and exclusion criteria, 161 records were excluded due to disa- 
Table 2. Inclusion and exclusion criteria

\begin{tabular}{|c|c|c|}
\hline Item & Inclusion criteria & Exclusion criteria \\
\hline Period & Until 09/2020 & $\mathrm{n} / \mathrm{a}$ \\
\hline Language of the publication & English, Czech & Non-English, non-Czech \\
\hline Type of article & $\begin{array}{l}\text { Original research: quantitative, qualitative, mix method, } \\
\text { validation and methodological study. Article published in } \\
\text { a peer-reviewed journal, with published results }\end{array}$ & $\begin{array}{c}\text { Any article that was not published in a peer-reviewed } \\
\text { journal } \\
\text { Study protocols }\end{array}$ \\
\hline Age & $\begin{array}{l}\text { Children up to } 7 \text { years of age } \\
\text { OR } \\
\text { At least one subgroup were preschoolers }\end{array}$ & Children outside the given age range \\
\hline Study focus & $\begin{array}{l}\text { Assessment of pain in children using an assessment tool, } \\
\text { includes a description of the pain tool }\end{array}$ & No description of the pain tool \\
\hline Geographical area of interest & $\begin{array}{l}\text { Any geographical area, any environment (hospital, } \\
\text { community, clinic, ambulance) }\end{array}$ & None \\
\hline
\end{tabular}

greement. After the gradual elimination of irrelevant studies, 51 articles remained to be studied in detail after obtaining and reading their full-text content. Based on this evaluation of the full texts, 14 studies were selected for final use in the scoping review. The time range of the selected studies was from 1985 to 2018.
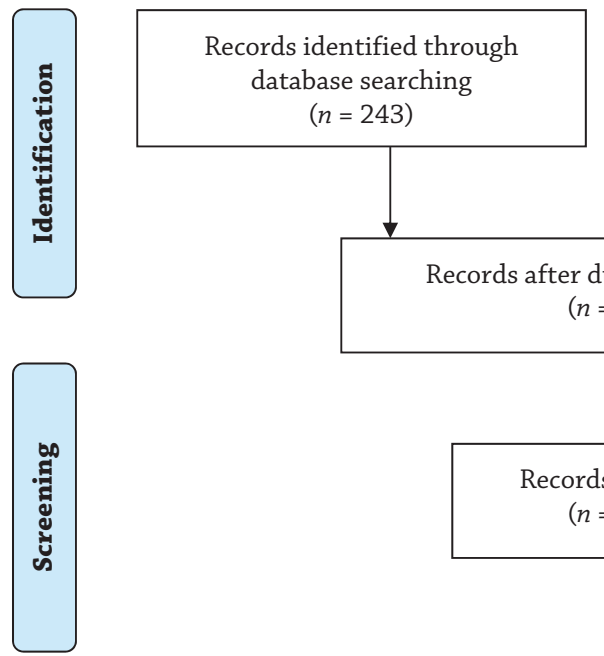

Records after duplicates removed

$(n=212)$

Additional records identified through other sources $(n=10)$
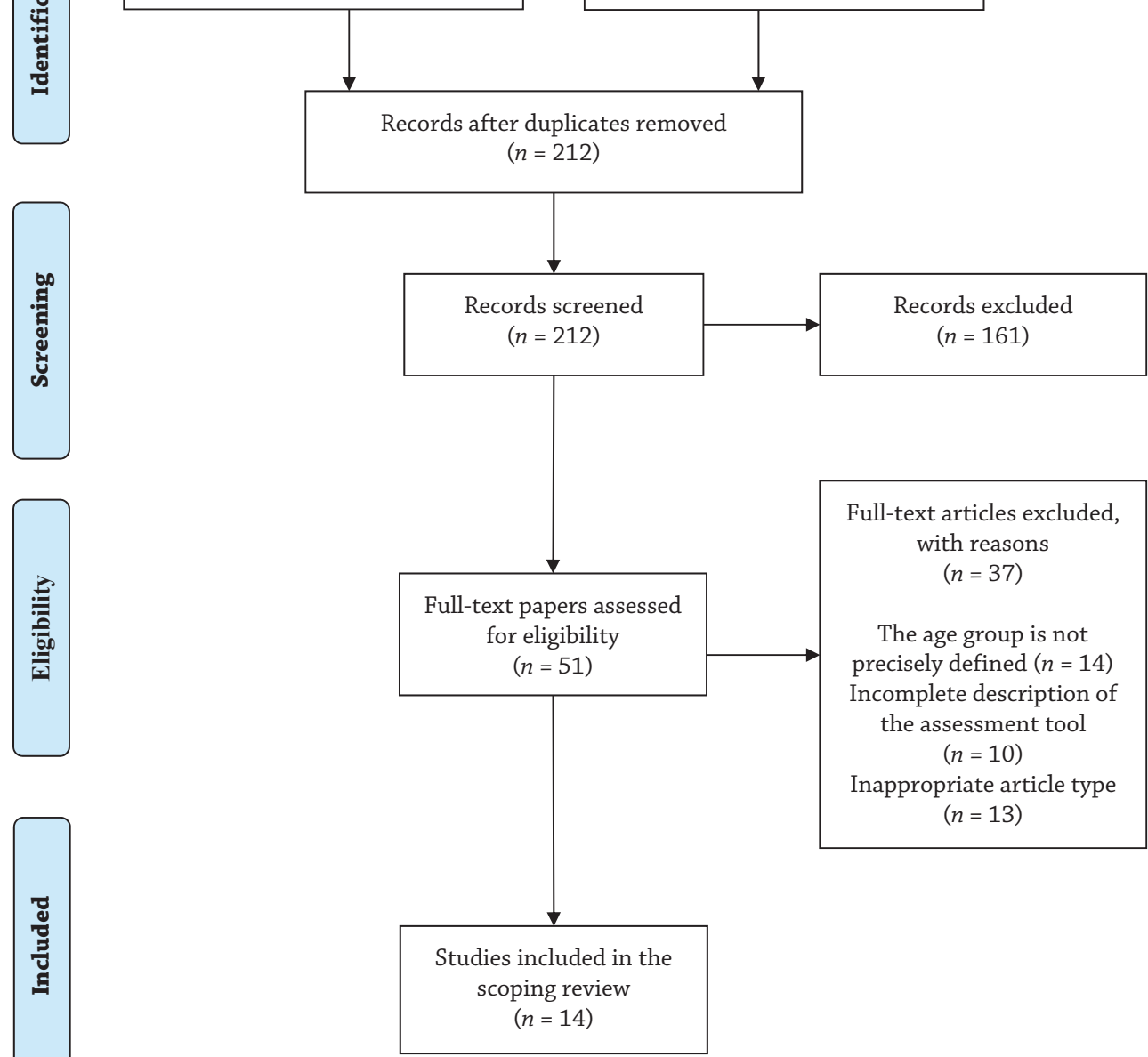

Full-text articles excluded, with reasons

$(n=37)$

The age group is not precisely defined $(n=14)$ Incomplete description of

the assessment tool $(n=10)$

Inappropriate article type $(n=13)$

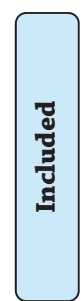

Fig. 1. Search results and study selection and inclusion process (Moher et al., 2009) 


\section{Results}

Many studies have evaluated several tools for assessing pain in children, mostly during the process of their validation. The authors compared the evaluation tools and then drew conclusions about validity and reliability. Most assessment tools were generally developed for any type of pain, other tools focused on specific pain (Chang et al., 2015). One validation study evaluated distress along with procedural pain (Ambuel et al., 1992).

\section{Characteristics of the included studies}

Of the total 14 studies selected for the review, 9 were validation studies and 5 were cross-sectional analytical studies.
Some studies focused directly on early childhood, others provided detailed information on the entire childhood period from birth to adulthood, with assessment tools always assigned to a specific age and level of development. According to the number of participants, the studies were equally diverse, some included only a small number of children, others were large (Table 3 ).

\section{Context analysis}

Most studies were carried out in the USA $(n=7)$, followed by Canada $(n=3)$, Australia $(n=2)$, Sweden $(n=1)$ and South Korea $(n=1)$. Data for research were mostly obtained in hospitals $(n=11)$, but also in clinics $(n=2)$ or in the community $(n=1)$.

Table 3. Overview of suitable studies $(n=14)$

\begin{tabular}{|c|c|c|c|c|c|}
\hline Author's name & Country of study & Context & Age of participants & Sample size & Type of article \\
\hline Ambuel et al., 1992 & USA & hospital & 0 to 18 years & 37 & validation study \\
\hline Beyer et al., 1990 & USA & hospital & 3 to7 years & 25 & analytical cross-sectional study \\
\hline Breau et al., 2001 & Canada & $\begin{array}{c}\text { immunization clinic } \\
\text { (ambulance) }\end{array}$ & 4 to 5 years & 123 & analytical cross-sectional study \\
\hline Chang et al., 2015 & Canada & hospital & 1 to 6 years & 44 & validation study \\
\hline Goodenough et al., 1997 & Australia & immunization clinic & 4 to 6 years & 50 & analytical cross-sectional study \\
\hline Hesselgard et al., 2007 & Sweden & hospital & 1 to 7 years & 76 & validation study \\
\hline Hunter et al., 2000 & Australia & community & 3 to 6 years & 135 & validation study \\
\hline Jung et al., 2018 & Korea & hospital & 4 to 7 years & 163 & validation study \\
\hline McGrath et al., 1985 & Canada & hospital & 1 to 7 years & 30 & validation study \\
\hline Merkel et al., 1997 & USA & hospital & 2 months to 7 years & 89 & validation study \\
\hline Singer et al., 2002 & USA & hospital & 4 to 7 years & 63 & analytical cross-sectional study \\
\hline Tarbell et al., 1992 & USA & hospital & 1 to 5 years & 74 & validation study \\
\hline Thirion et al., 2015 & USA & hospital & 3 to 5 years & 38 & analytical cross-sectional study \\
\hline Willis et al., 2003 & USA & hospital & 3 to 7 years & 30 & validation study \\
\hline
\end{tabular}

\section{Content analysis}

The researchers included the following instruments among the self-assessment tools for children $(n=8)$ : Smiley Analog Scale (SAS) (Singer et al., 2002), Faces Pain Scale (FPS) (Breau et al., 2001; Goodenough et al., 1997; Hunter et al., 2000); Poker Chip Tool, Visual Analogue Toy, Verbal rating scale (Goodenough et al., 1997), Pain Block scale (Jung et al., 2018), Pieces of Hurt (Thirion et al., 2015), Analogue Chromatic Continuous Scale (ACCS), Oucher (Beyer et al., 1990).

Next, behavioural assessment tools for children were identified ( $n=11)$ : Visual Analog Scale (VAS) (Ambuel et al., 1992; Breau et al., 2001; McGrath et al., 1985; Singer et al., 2002), Behavioural checklist (Goodenough et al., 1997), FLACC (Face, Legs, Activity, Cry, Consolability) (Chang et al., 2015; Merkel et al., 1997; Willis et al., 2003), Toddler-Preschooler Postoperative Pain Scale (TPPPS) (Chang et al., 2015; Tarbell et al., 1992), CHEOPS (Children's Hospital of Eastern Ontario Pain Scale) (Beyer et al., 1990; Chang et al., 2015, Hesselgard et al., 2007; McGrath et al., 1985; Tarbell et al., 1992), Behavioural Observational Pain Scale (BOPS) (Hesselgard et al., 2007), COMFORT Scale (Ambuel et al., 1992), Child Facial Coding System (CFCS) (Breau et al., 2001; Chang et al., 2015), Riley Infant Pain Scale (RIPS), Pre-verbal, Early Verbal Pediatric Pain Scale (PEPPS), and Children and Infants' Postoperative Pain Scale (CHIPPS) (Chang et al., 2015).
Behavioural assessment tools are based on the child's external manifestations that adults observe in them. Most evaluation tools are processed into tables that contain the relevant criteria corresponding to the evaluation method. Adults enter their ratings in these tables of individual assessment tools and points are assigned. The resulting number of points provides information about the child's pain. Self-report evaluation tools are made in creative ways and always for a specific age period so that they are as understandable as possible and the child can easily work with them. There are mostly pictures: cubes, faces, toys, and animals. Some scientists also focused on using colours. Some have a method of assessing pain based on colour scales, while others report that colours are misleading and the child is affected by the colour when he or she evaluates his or her own pain. These experts support the use of images in black and white (Table 4).

In their study, Merkel et al. (1997) evaluated the reliability and validity of the FLACC pain tool in children aged 2 months to 7 years. The results confirm the reliability and the validation of the FLACC tool. This method is easy to use for clinical purposes, easy to incorporate into pain documentation forms and is also suitable for further research. Willis et al. (2003) evaluated the validity of FLACC pain assessments in children aged 3-7 years. The result represents a significant and positive correlation for the whole sample of children aged 5-7 years, but 
Table 4. Characteristics of studies

\begin{tabular}{|c|c|c|c|c|c|c|}
\hline Author's name & $\begin{array}{l}\text { Name of } \\
\text { study }\end{array}$ & Type & Description & $\begin{array}{l}\text { Aspects of pain/ } \\
\text { type of pain }\end{array}$ & $\begin{array}{l}\text { Non-pain } \\
\text { aspects }\end{array}$ & $\begin{array}{l}\text { Psychometric } \\
\text { validation }\end{array}$ \\
\hline \multirow[t]{2}{*}{ Ambuel et al., 1992} & $\begin{array}{l}\text { COMFORT } \\
\text { Scale }\end{array}$ & behavioral & $\begin{array}{l}8 \text { items (alertness, face, muscle tone, } \\
\text { agitation, movement, heart rate, } \\
\text { respiration, blood pressure) }\end{array}$ & \multirow[t]{2}{*}{ procedure pain } & \multirow[t]{2}{*}{ Distress } & \multirow{2}{*}{$\begin{array}{c}\text { Interrater reliability: } \\
\begin{array}{c}r=0.84, p<0.01 \\
\text { Validity } r=0.75 \\
p<0.01\end{array}\end{array}$} \\
\hline & VAS & behavioral & $100-\mathrm{mm}$ visual analogue scale & & & \\
\hline \multirow{3}{*}{ Beyer et al., 1990} & CHEOPS & behavioral & $\begin{array}{c}6 \text { items (cry, facial, verbal, torso, touch, } \\
\text { legs) }\end{array}$ & \multirow{3}{*}{ major surgery } & & \\
\hline & ACCS & self-report & 100 mm slide-rule & & & \\
\hline & Oucher & self-report & poster with numbers and pictures & & & \\
\hline \multirow{3}{*}{ Breau et al., 2001} & CFCS & behavioral & 13 facial action & \multirow{3}{*}{$\begin{array}{l}\text { immunization } \\
\text { pain }\end{array}$} & & \\
\hline & FPS & self-report & 7 faces & & & \\
\hline & VAS & behavioral & 100-mm visual analog scale & & & \\
\hline \multirow{7}{*}{ Chang et al., 2015} & CFCS & behavioral & 13 facial action & \multirow{7}{*}{$\begin{array}{l}\text { major surgery, } \\
\text { postoperative } \\
\text { pain }\end{array}$} & & \multirow{7}{*}{$\begin{array}{c}\text { Intercoder reliability: } \\
\text { (Intraclass correlation) } \\
\text { ICC } 0.75 \\
\text { Effective reliability: } \\
R=0.73-0.77, p>0.70 \\
\text { Criterion validity } \\
\text { Face validity } \\
\text { Content validity }\end{array}$} \\
\hline & CHEOPS & behavioral & $\begin{array}{c}6 \text { items (cry, facial, verbal, torso, touch, } \\
\text { legs) }\end{array}$ & & & \\
\hline & FLACC & behavioral & $\begin{array}{c}5 \text { items (face, legs, activity, crying, } \\
\text { consolation) }\end{array}$ & & & \\
\hline & RIPS & behavioral & $\begin{array}{l}6 \text { items (facial, body movement, sleep, } \\
\text { verbal, consolability, response to touch) }\end{array}$ & & & \\
\hline & PEPPS & behavioral & $\begin{array}{c}7 \text { items (heart rate, facial, cry, } \\
\text { consolability, body posture, sociability, } \\
\text { feeding) }\end{array}$ & & & \\
\hline & CHIPPS & behavioral & $\begin{array}{l}5 \text { items (crying, facial expression, } \\
\text { posture of the trunk, posture of the } \\
\text { legs, motor restlessness) }\end{array}$ & & & \\
\hline & TPPPS & behavioral & $\begin{array}{c}7 \text { items in } 3 \text { categories (vocal, facial and } \\
\text { body expression) }\end{array}$ & & & \\
\hline \multirow{5}{*}{$\begin{array}{l}\text { Goodenough et al., } \\
1997\end{array}$} & FPS & self-report & 7 faces & \multirow{5}{*}{$\begin{array}{l}\text { intramuscular } \\
\text { injections }\end{array}$} & & \\
\hline & $\begin{array}{l}\text { Poker Chip } \\
\text { Tool }\end{array}$ & self-report & $1-4$ chips & & & \\
\hline & $\begin{array}{l}\text { Visual } \\
\text { Analogue } \\
\text { Toy }\end{array}$ & self-report & wooden pole with a toy & & & \\
\hline & $\begin{array}{l}\text { Verbal } \\
\text { rating scale }\end{array}$ & self-report & written question with answers & & & \\
\hline & $\begin{array}{l}\text { Behavioral } \\
\text { checklist }\end{array}$ & behavioral & $\begin{array}{c}4 \text { domains (facial, vocal, verbal, motor } \\
\text { reactions) }\end{array}$ & & & \\
\hline \multirow[b]{2}{*}{$\begin{array}{l}\text { Hesselgard et al., } \\
2007\end{array}$} & BOPS & behavioral & $\begin{array}{c}3 \text { items (facial expression, verbalization, } \\
\text { body position) }\end{array}$ & \multirow[b]{2}{*}{$\begin{array}{l}\text { postoperative } \\
\text { pain }\end{array}$} & & \multirow{2}{*}{$\begin{array}{l}\text { Construct validity, } \\
\text { Interrater reliability: } \\
\text { (Weighted kappa) } \\
\text { kw 0.86-0.95 } \\
\text { Concurrent validity } \\
r_{\mathrm{s}} 0.871, p<0.001\end{array}$} \\
\hline & CHEOPS & behavioral & $\begin{array}{l}6 \text { items (cry, facial, verbal, torso, touch, } \\
\text { legs) }\end{array}$ & & & \\
\hline Hunter et al., 2000 & FPS & self-report & 7 faces & any pain & & $\begin{array}{c}\text { Reliability: correlation } \\
0.35-0.81\end{array}$ \\
\hline Jung et al., 2018 & Pain Block & self-report & 5 items (game blocks) & any pain & & $\begin{array}{c}\text { Convergent construct } \\
\text { validity: } R=0.82, \\
\text { Discriminative validity: } \\
p<0.001 \\
\text { Reliability: } p>0.05\end{array}$ \\
\hline \multirow{2}{*}{$\begin{array}{l}\text { McGrath et al., } \\
1985\end{array}$} & CHEOPS & behavioral & $\begin{array}{c}6 \text { items (cry, facial, verbal, torso, touch, } \\
\text { legs) }\end{array}$ & \multirow{2}{*}{$\begin{array}{l}\text { postoperative } \\
\text { pain }\end{array}$} & & \multirow{2}{*}{$\begin{array}{l}\text { Interrater reliability: } \\
\text { agreement } 90-99.5 \% \\
\text { Social validity: } r_{\mathrm{s}} 0.85 \text {, } \\
\qquad p<0.05\end{array}$} \\
\hline & VAS & behavioral & 100 -mm visual analogue scale & & & \\
\hline
\end{tabular}


Table 4. (continued)

\begin{tabular}{|c|c|c|c|c|c|c|}
\hline Author's name & $\begin{array}{l}\text { Name of } \\
\text { study }\end{array}$ & Type & Description & $\begin{array}{l}\text { Aspects of pain/ } \\
\text { type of pain }\end{array}$ & $\begin{array}{l}\text { Non-pain } \\
\text { aspects }\end{array}$ & $\begin{array}{l}\text { Psychometric } \\
\text { validation }\end{array}$ \\
\hline Merkel et al., 1997 & FLACC & behavioral & $\begin{array}{l}5 \text { items (face, legs, activity, crying, } \\
\text { consolation) }\end{array}$ & $\begin{array}{c}\text { surgical } \\
\text { procedure, } \\
\text { postoperative } \\
\text { pain }\end{array}$ & & $\begin{array}{c}\text { Interrater reliability } \\
r 0.94, p<0.001 \\
\text { Construct validity } \\
r 0.41, p<0.005\end{array}$ \\
\hline \multirow{2}{*}{ Singer et al., 2002} & SAS & self-report & 5 different faces & \multirow{2}{*}{\multicolumn{2}{|c|}{ procedure pain }} & \\
\hline & VAS & behavioral & $100-\mathrm{mm}$ visual analogue scale & & & \\
\hline \multirow{2}{*}{ Tarbell et al., 1992} & TPPPS & behavioral & $\begin{array}{c}7 \text { items in } 3 \text { categories (vocal, facial and } \\
\text { body expression) }\end{array}$ & \multirow{2}{*}{\multicolumn{2}{|c|}{$\begin{array}{c}\text { surgical } \\
\text { procedure, } \\
\text { postoperative } \\
\text { pain }\end{array}$}} & \multirow{2}{*}{$\begin{array}{l}\text { Internal reliability: } \\
\text { Cronbach's alpha }=0.88 \\
\text { Interrater reliability: } \\
\text { kappa } 0.53 \text { to } 0.78 \\
\text { Concurrent validity }\end{array}$} \\
\hline & CHEOPS & behavioral & $\begin{array}{l}6 \text { items (cry, facial, verbal, torso, touch, } \\
\text { legs) }\end{array}$ & & & \\
\hline Thirion et al., 2015 & $\begin{array}{l}\text { Pieces of } \\
\text { Hurt }\end{array}$ & self-report & 1-4 chips & $\begin{array}{c}\text { postoperative } \\
\text { pain }\end{array}$ & & \\
\hline Willis et al., 2003 & FLACC & behavioral & $\begin{array}{c}5 \text { items (face, legs, activity, crying, } \\
\text { consolation) }\end{array}$ & $\begin{array}{c}\text { surgical } \\
\text { procedure, } \\
\text { postoperative } \\
\text { pain }\end{array}$ & & $\begin{array}{l}\text { Construct validity: } \\
r 0.584, p=0.001\end{array}$ \\
\hline
\end{tabular}

unfortunately not for children < age 5 . A study by Tarbell et al. (1992) evaluated the reliability and validity of TPPPS in postoperative pain in children aged $1-5$ years. In conclusion, it was found to have a satisfactory internal reliability and inter-rater reliability. In their study, Jung et al. (2018) attempted to develop and validate the Pain Block scale for children aged 4 to 7 years. Good results suggest that the Pain Block scale is a suitable tool for assessing pain in children aged 4 to 7 years (in those who can count to 5).

A study by Hesselgard et al. (2007) evaluated the validity and reliability of the BOPS tool for the assessment of postoperative pain in children aged 1-7 years. The results demonstrated high reliability and validity. The method is simple, clear and easy to use. In their study, McGrath et al. (1985) described the development of the CHEOPS scale. This is an observation pain scale for measuring postoperative pain in children aged 1-7 years. The results showed excellent reliability and good evidence of validity. A simple scoring method seems to be very effective. Hunter et al. (2000) evaluated preschool and school age children in three groups (3.5-4.5; 4.5-5.5; 5.5-6.5 years) in their psychometric study of the Facial Pain Scale (FPS). The results of the study suggest that it can be applied to very young children. Ambuel et al. (1992) focused on another use of the COMFORT rating scale primarily developed for pain assessment for its use in the assessment of distress. The method evaluates the body's responses and physiological functions.

In their study, Chang et al. (2015) evaluated a large number of pain scales (CHEOPS, FLACC, RIPS, PEPPS, CHIPPS, TPPPS and CFCS). The use of the individual scales depended on different criteria, which resulted in a wide range of scores. This research suggests the need for further investigation and that there is a need to develop objective coding observational measures for a standardized assessment of pain in children.

\section{Description of evaluation tools}

SAS has 5 round faces in black and white with different expressions, from frowning (severe pain) to a wide smile (no pain). Each face is assigned a numerical value from 0 (no pain) to 4 (severe pain) (Singer et al., 2002). VAS is a $100 \mathrm{~mm}$ long line, the left side shows no pain and the right side represents the worst pain (Ambuel et al., 1992; Breau et al., 2001; McGrath et al., 1985; Singer et al., 2002). FPS contains 7 images of a schematic face represented by a line drawing which expresses increasing levels of pain intensity, from no pain on the left side of the face to the greatest possible pain on the right side of the face (Breau et al., 2001; Goodenough et al., 1997; Hunter et al., 2000).

The Pieces of Hurt Tool formerly known as the Poker Chip Tool presents a number of different versions. During the first variant, the patient is asked if something hurts right now. If the answer is no, zero is recorded. If the answer is yes, four poker chips are presented - with one chip representing "small hurt" and four chips representing "the most hurt". Other authors present one chip as "a bit" of pain, two chips show "a little more" pain, three chips represent "even more" pain, and four chips represent "the most" pain. Another version presents one chip as "a bit" of damage, two chips represent "a little more", three chips show "even more" damage, and four chips represent "the most" damage. A different version of the tool consists of one white chip that represents no pain and four red chips that symbolize pain levels 1 to 4 . The specific version has different poker chip sizes, where the chip size represents the intensity of the pain (Goodenough et al., 1997; Thirion et al., 2015).

The Visual Analogue Toy consists of a koala toy on a vertical $20 \mathrm{~cm}$ wooden stick. The intensity of the pain increases from the bottom part of the rod upwards. The toy koala moves according to the degree of pain, from the lower part representing no pain to the top symbolizing the greatest possible pain. The verbal rating scale is written in black on a large white background: How much did you hurt: "not at all", "a little", "more", "the most" hurt? An ordinal numerical scale $(0,1,2$ and 3$)$ is assigned to the individual levels of pain assessment (Goodenough et al., 1997).

The behavioural checklist contains 4 groups (facial, vocal, verbal, motor reactions) and each of them further consists of other specifics describing the pain, to which points are assigned (from 0 to 3 severe) (Goodenough et al., 1997). FLACC contains 5 categories including face, legs, activity, crying and consolation, to which values are assigned 0, 1 and 2 (Chang et 
al., 2015; Merkel et al., 1997; Willis et al., 2003). TPPPS consists of 7 items in three categories: vocal pain expression, facial expression, and body pain expression, total score 0 to 7 (Chang et al., 2015; Tarbell et al., 1992). CHEOPS includes 6 categories: crying, face, verbal, torso, touch and legs; it is scored from 0 to 2 or 1 to 3 for each activity and the total score is between 4 and 13 (Beyer et al., 1990; Chang et al., 2015; Hesselgard et al., 2007; McGrath et al., 1985; Tarbell et al., 1992). Pain Block is a set of pictures in the form of game blocks ( $1-5$ blocks) where increasing the number of blocks shows the intensity of pain (Jung et al., 2018). BOPS evaluates facial expression, verbalization and body position, each category is rated from 0 to 2 (Hesselgard et al., 2007).

COMFORT has 8 items: 5 behavioural variables (alertness, facial tension, muscle tone, agitation, and movement) and 3 physiological variables (heart rate, respiration, and blood pressure), each is scored between 1 and 5 (Ambuel et al., 1992). CFCS evaluates 13 facial actions: brow lower, squint, eye squeeze, nose wrinkle, nasolabial furrow, cheek raise, upper lip raise, lip corner pull, vertical mouth, horizontal mouth, blink, flared nostril, open lips (Breau et al., 2001; Chang et al., 2015). ACCS is a caliper; on one side is a colour scale (the darker the colour, the greater the pain), on the other side a $100 \mathrm{~mm}$ ruler is printed (Beyer et al., 1990). The Oucher is a poster; on the left side is a numerical scale from 0 to 100 and on the right side there are 6 photos of children's faces expressing pain (Beyer et al., 1990). RIPS has 6 categories: facial, body movement, sleep, verbal/vocal, consolability, response to movement/touch, total score 0 to 18. PEPPS has 7 categories: heart rate, facial, cry (audible/visible), consolability/state of restfulness, body posture, sociability, sucking/feeding, total score 0 to 26. CHIPPS is composed of 5 categories: crying, facial expression, posture of the trunk, posture of the legs, and motor restlessness, total score 0 to 10 (Chang et al., 2015).

\section{Discussion}

As described above, pain self-report tools can only be used from a certain age and from the certain development of cognitive knowledge. Self-report tools include those assessment tools where the child assesses his or her own pain, whilst behaviour assessment focuses on observing various aspects of behaviour that generally suggest the person is in pain, e.g. frowning. While the number of different identified behaviour assessment tools was slightly higher $(n=11)$ than the number of different self-report tools $(n=8)$, self-report instruments were used for children as young as 3 years (Beyer et al., 1990; Hunter et al., 2000; Thirion et al., 2015).

However, the results were not satisfactory in all of these studies. For example, Beyer et al. (1990) found discordance between self-report and behaviour pain measures when the correlation was between 0.45 and 0.67 (for the age group 3-7). The authors advocate the use of behavioural cues as the primary method, but whenever possible, they recommend using these in conjunction with children's self-reports.

For older children, i.e. ages 4-7, the results concerning the use of self-report instruments were more convincing. Jung et al. (2018) studied the use of self-report in children aged 4 to 7. Their study showed the instrument that consisted of 5 game blocks had high construct validity $(r=0.82)$ and discriminative validity; however, the reliability showed low correlation results. Overall, apart from the study by Jung et al. (2018) the other studies that included the use of a self-report instrument did not examine their psychometric properties.
Behavioural methods are used without age restriction for all those who, for whatever reason (lack of cognitive development, coma, etc.), cannot assess their pain. The VAS scale is the most frequently used; for its simplicity it is used by both parents and healthcare professionals (Ambuel et al., 1992; Breau et al., 2001; McGrath et al., 1985; Singer et al., 2002). The instrument most frequently examined was the CHEOPS (Beyer et al., 1990; Chang et al., 2015; Hesselgard et al., 2007; McGrath et al., 1985; Tarbell et al., 1992) and its validity and reliability were satisfactory. In contrast, the FLACC, which was examined in two studies (Chang et al., 2015; Merkel et al., 1997; Willis et al., 2003), had only moderate construct validity $(r=0.41-0.584)$, while its inter-rater reliability was satisfactory. The most frequently used methods in children are the VAS and FLACC, depending on their current health status and cognitive development.

Three studies compared the use of self-report instruments versus behavioural instruments. Healthcare professionals tend to rely more on behavioural assessment. Researchers recommend that whenever possible, behavioural pain measurements should be used in conjunction with a self-repot evaluation (Beyer et al., 1990; Breau et al., 2001; Goodenough et al., 1997). Von Baeyer (2009) states that the standard use of self-assessment in children aged three and four is not well established; many important theoretical and practical issues need to be taken into account. The cognitive and social development of young children limits their self-reporting. Obtaining valid information from preschool children requires establishing a trusting relationship. In their study, Emmott et al. (2017) concluded that three-year-old and four-year-old children are usually unable to assess pain using a standard self-report due to their immaturity.

It is clear that pain assessment in preschoolers is not entirely straightforward and nurses should engage in further research so that they can provide appropriate nursing care to this age group.

\section{Limitations of the study}

Most experts focus on pain assessment in institutional health care, but children also experience pain outside of these facilities. The limitations of this review lie mainly in the fact that the search included English and Czech contributions only. It is possible that studies on this topic are published in other languages as well.

\section{Conclusions}

All the presented pain assessment tools evaluate pain in different ways, but always with the same goal: to correctly evaluate the child's pain and then treat it in the best way. Particularly in young children, it is desirable to include more methods in assessing pain and to assess more aspects of pain and provide them with the right treatment. In preschool children (aged $3-7)$, it is possible to use self-report if they have reached sufficient cognitive maturity and are willing to cooperate. The topic of assessing pain in childhood is becoming more and more important. European scientists and experts need to pay more attention to this issue, because aside from one identified Swedish study, all the others studies come from non-European countries. Research studies that evaluate the psychometric properties of self-report instruments are also needed. Finally, it would be worthwhile to carry out a systematic review to assess the quality of the studies offered. 


\section{Ethical aspects and conflict of interests}

The authors have no conflict of interests to declare.

\section{Funding}

The publication was created within the IGA UP project with the registration number IGA_FZV_2021_003.

\section{Hodnocení bolesti u předškoláků (3-7 let): Přehled existujících nástrojů}

\section{Souhrn}

Cíl: Cílem přehledové studie bylo posoudit dostupné vědecké poznatky o hodnocení bolesti u dětí předškolního věku (3-7 let). Získané informace jsou základem pro další výzkum.

Metody: Data byla sbírána pomocí klíčových slov dle PCC s využitím booleovských operátorů, které jsme použili pro prohledávání vědeckých elektronických databází. Klíčová slova vycházela z výzkumné otázky se zaměřením na konkrétní populaci, koncept a kontext. Vyhledávání proběhlo ve vědeckých databázích: PubMed, ProQuest, OVID, EBSCOhost.

Výsledky: Celkem bylo identifikováno 243 článků a přidáno dalších 10 zdrojů z referenčních seznamů vyhledaných článků. Prvotním zkoumáním bylo vybráno 51 článků a po následné kritické analýze bylo finálně využito 14 studií pro přehledový článek. Závěr: Výsledky studie potvrdily, že téma hodnocení bolesti u dětí nabývá na významu. Všechny prezentované nástroje pro posouzení bolesti hodnotily bolest různými způsoby, ale vždy se stejným cílem: správně vyhodnotit bolest dítěte a poté s ní pracovat co nejlépe. Zejména u malých dětí je vhodné zahrnout více metod hodnocení bolesti a posoudit různé aspekty pro poskytnutí té nejlepší léčby.

Kličová slova: bolest; dítě; hodnoticí nástroj; management bolesti; pediatrie; škála bolesti

\section{References}

1. Ambuel B, Hamlett KW, Marx CM, Blumer JL (1992). Assessing distress in pediatric intensive care environments: the COMFORT scale. J Pediatr Psychol 17(1): 95-109. DOI: 10.1093/jpepsy/17.1.95.

2. Besenski LJ, Forsyth SJ, von Baeyer CL (2007). Screening young children for their ability to use self-report pain scales. Pediatric Pain Letter 9(1): 1-6.

3. Beyer JE, McGrath PJ, Berde CB (1990). Discordance between self-report and behavioral pain measures in children aged 3-7 years after surgery. J Pain Symptom Manage 5(6): 350-356. DOI: 10.1016/0885-3924(90)90029-j.

4. Brand K, Al-Rais A (2019). Pain assessment in children. Anaesth Intensive Care Med 20(6): 314-317. DOI: 10.1016/j. mpaic.2019.03.003.

5. Breau LM, McGrath PJ, Craig KD, Santor D, Cassidy KL, Reid GJ (2001). Facial expression of children receiving immunizations: a principal components analysis of the child facial coding system. Clin J Pain 17(2): 178-186. DOI: 10.1097/00002508200106000-00011.

6. Chan JY, von Baeyer CL (2016). Cognitive developmental influences on the ability of preschool-aged children to self-report their pain intensity. Pain 157(5): 997-1001. DOI: 10.1097/j.pain.0000000000000476.

7. Chang J, Versloot J, Fashler SR, McCrystal KN, Craig KD (2015). Pain assessment in children: validity of facial expression items in observational pain scales. Clin J Pain 31(3): 189-197. DOI: 10.1097/AJP.0000000000000103.

8. Emmott AS, West N, Zhou G, Dunsmuir D, Montgomery CJ, von Baeyer CL, et al. (2017). Validity of Simplified Versus Standard Self-Report Measures of Pain Intensity in Preschool-Aged Children Undergoing Venipuncture. J Pain 18(5): 564-573. DOI: 10.1016/j.jpain.2016.12.015.

9. Goodenough B, Addicoat L, Champion GD, McInerney M, Young B, Juniper K, Ziegler JB (1997). Pain in 4- to 6-year-old children receiving intramuscular injections: a comparison of the Faces Pain Scale with other self-report and behavioral measures. Clin J Pain 13(1): 60-73. DOI: 10.1097/00002508-19970300000009.

10. Hesselgard K, Larsson S, Romner B, Strömblad LG, Reinstrup P (2007). Validity and reliability of the Behavioural Observational
Pain Scale for postoperative pain measurement in children 1-7 years of age. Pediatr Crit Care Med 8(2): 102-108. DOI: 10.1097/01.PCC.0000257098.32268.AA.

11. Hunter M, McDowell L, Hennessy R, Cassey J (2000). An evaluation of the Faces Pain Scale with young children. J Pain Symptom Manage 20(2): 122-129. DOI: 10.1016/s08853924(00)00171-8.

12. International Association for the Study of Pain (IASP) (2021). Terminology. [online] [cit. 2021-03-29]. Available from: https:// www.iasp-pain.org/terminology?navItemNumber $=576$

13. Jung JH, Lee JH, Kim DK, Jung JY, Chang I, Kwon H, et al. (2018). Validation of the "Pain Block" concrete ordinal scale for children aged 4 to 7 years. Pain 59(4): 656-662. DOI: 10.1097/j. pain.0000000000001131.

14. McGrath PJ, McAlpine L (1993). Psychologic perspectives on pediatric pain. J Pediatr 122(5): S2-S8. DOI: 10.1016/S00223476(11)80002-8.

15. McGrath P, Goodman JT, Johnson G, Schillinger J, Dunn J, Chapman JA (1985). CHEOPS: a behavioral scale for rating postoperative pain in children. Adv Pain Res Ther 9: 395-402.

16. Merkel SI, Voepel-Lewis T, Shayevitz JR, Malviya S (1997). The FLACC: a behavioral scale for scoring postoperative pain in young children. J Pediatr Nurs 23(3): 293-297.

17. Moher D, Liberati A, Tetzlaff J, Altman DG (2009). Preferred reporting items for systematic reviews and meta-analyses: the PRISMA statement. BMJ 339: b2535-b2535. DOI: 10.1136/ bmj.b2535.

18. Peters MDJ, Godfrey C, McInerney P, Munn Z, Tricco AC, Khalil H (2020). Chapter 11: Scoping Reviews (2020 version). In: Aromataris E, Munn Z (Eds). JBI Manual for Evidence Synthesis, JBI, 2020. DOI: 10.46658/JBIMES-20-12.

19. Plevová I, Slowik R, Kulhánková J, Buchwaldková D, Tydlačková R (2012). Hodnocení bolesti u dětí. Využití měřicích nástrojů v ošetřovatelské praxi. Pediatr praxi 13(3): 193-197.

20. Sedlářová $P$ (2008). Základní ošetřovatelská péče $v$ pediatrii. Praha: Grada, 248 p.

21. Singer AJ, Gulla J, Thode HC, Jr. (2002). Parents and practitioners are poor judges of young children's pain severity. Acad Emerg Med 9(6): 609-12. DOI: 10.1111/j.15532712.2002.tb02298.x.

22. Stanley M, Pollard D (2013). Relationship between knowledge, attitudes, and self-efficacy of nurses in the management of pediatric pain. Pediatr Nurs 39(4): 165-171. 
23. Tarbell SE, Cohen TI, Marsh JL (1992). The Toddler-Preschooler Postoperative Pain Scale: an observational scale for measuring postoperative pain in children aged 1-5. Pain 50(3): 273-280. DOI: 10.1016/0304-3959(92)90031-6.

24. Thirion J, O’Riordan MA, Stormorken A (2015). Revisiting the Pieces of Hurt pain assessment tool - do the pieces matter? Pediatric Pain Letter 17(1): 1-4.

25. von Baeyer CL (2009). Children's self-report of pain intensity: what we know, where we are headed. Pain Res Manag 14(1): 39-45. DOI: $10.1155 / 2009 / 259759$.
26. von Baeyer CL, Uman LS, Chambers CT, Gouthro A (2011). Can we screen young children for their ability to provide accurate self-reports of pain? Pain 152(6): 1327-1333. DOI: 10.1016/j. pain.2011.02.013.

27. Willis MHW, Merkel SI, Voepel-Lewis T, Malviya S (2003). FLACC Behavioral Pain Assessment Scale: a comparison with the child's self-report. Pediatr Nurs 29(3): 195-198. 